\title{
Normative quality factors of grain of winter wheat on black earth in conditions of Forest-steppe and Steppe
}

\author{
M. Lisovyi, \\ Doctor of Agricultural Sciences \\ National Scientific Center "Institute of Soil Science and Agrochemistry named after O.N. Sokolovsky»
}

The purpose. To determine influence of natural fertility of black earth of different types and artificial fertilizers on protein and gluten content and vitreousness of grain of winter wheat in conditions of Forest-steppe and Steppe. Methods. Mathematical-and-statistical analysis of data of field experiments with fertilizers. Results. Normative quality factors of grain of wheat for the basic types of black earth and under condition of application of artificial fertilizers are specified. The skeleton map of the content of gluten in grain of winter wheat of in Ukraine is made. Conclusions. Quality of grain of winter wheat depends on fertility of different types of black earth and optimum doses of artificial fertilizers.

Key words: winter wheat, protein, gluten, vitreousness, black earth, fertilizer, skeleton map.

Winter wheat is one of the important food crops. The grain is used on the domestic market and also exported to foreign countries. In order to increase the export capacity of the country, it is not enough to enlarge the crop area of wheat, it is necessary to develop new scientific approaches to improving the quality of grain, that depends significantly on weather and climatic conditions, especially the conditions of soil moisture. Therefore, it is important to spread crops on the territory of Ukraine, taking into account natural zoning. The second important factor is the soil conditions, which also influence on the formation of grain quality [1, 2]. It is important to point at the fact that the quality of winter wheat grain, grown on the black earths (chernozem) of Ukraine, are higher as to compare to grain grown on other soils [3]. There are different types of chernozem. According to the morphological and genetic structure of the soil in the forest-steppe, chernozem is of two types: podzolized and typical; in the steppe - chernozems are ordinary and southern. Each of the types of chernozems is characterized by its fertility indices and peculiarities of climatic conditions for growing crops [4]. Therefore, their impact on the quality of the grain will be different. The third important factor in improving the quality of wheat is mineral fertilizers, the effect of which was studied by many local and foreign researchers $[5-7,10]$.

The purpose of the research is to determine the effect of natural fertility of various types of chernozem and mineral fertilizers on the protein content, gluten and vitreous appearance of winter wheat grain grown in foreststeppe and steppe zones.

Research methodology. To develop normative indicators of winter wheat grain quality, it is important to maintain and regularly update a relational database of field experiments with fertilizers that are carried out on the chernozem of forest-steppe and steppe zones. For each type of chernozem, samples of the contents of the protein, gluten and vitreous are formed. According to the results of the analysis of the correspondence of the data to the normal distribution of each sample (Shapiro-Ulyka criterion was applied) it was determined that the data distribution was significantly different from the normal one. Therefore, median is chosen for the central tendency of the values of the indicators, and for the variability of the indicator being studied, - the quantum scale (the difference between the upper and lower quartiles). In order to control the compliance of the data with the allowable value of the indicators, their minimum and maximum values are determined $[8,9]$. The calculations were conducted using the licensed EPP STATISTICA $10[9,10]$ and the SUBD MS Visual FoxPro Pro 9.0 .

Research results. Normative indicators of protein content in winter wheat grains are: on chernozem podzolized - 11,0\%, chernozem typical - 11,3, chernozem ordinary - 11,9, chernozem southern - 12,6\% (table). The application of mineral fertilizers increases the content of protein in wheat grains on the chernozems of the forest-steppe to $13.7 \%$, and the black soil of the Steppe - up to $14.2 \%$. 
Normative indicators of winter wheat grain quality ( based on results of field tests with the application of the fertilizers)

\begin{tabular}{|c|c|c|c|c|c|c|c|c|c|c|c|c|c|}
\hline \multirow{3}{*}{ Soil } & \multirow{3}{*}{$\begin{array}{l}\text { Quality } \\
\text { factors }\end{array}$} & \multicolumn{6}{|c|}{ Natural soil fertility } & \multicolumn{6}{|c|}{ Application of mineral fertilizers } \\
\hline & & \multirow{2}{*}{$\begin{array}{l}\text { Value of } \\
\text { the } \\
\text { indicator } \\
\mathrm{s}, \%\end{array}$} & \multicolumn{4}{|c|}{ Range of indicators, \% } & \multirow{2}{*}{$\begin{array}{l}\text { Num- } \\
\text { ber of } \\
\text { samp- } \\
\text { les }\end{array}$} & \multirow{2}{*}{$\begin{array}{l}\text { Value of } \\
\text { the } \\
\text { indica- } \\
\text { tors, } \%\end{array}$} & \multicolumn{4}{|c|}{ Range of indicators, $\%$} & \multirow{2}{*}{$\begin{array}{c}\text { Num- } \\
\text { ber of } \\
\text { samp- } \\
\text { les }\end{array}$} \\
\hline & & & $\begin{array}{l}\text { Lower } \\
\text { quar- } \\
\text { tiles }\end{array}$ & $\begin{array}{l}\text { Upper } \\
\text { quar- } \\
\text { tiles }\end{array}$ & $\begin{array}{c}\text { Lowest } \\
\text { indica- } \\
\text { tors }\end{array}$ & $\begin{array}{c}\text { Highest } \\
\text { indica- } \\
\text { tors }\end{array}$ & & & $\begin{array}{l}\text { Lower } \\
\text { quar- } \\
\text { tiles }\end{array}$ & $\begin{array}{l}\text { Upper } \\
\text { quar- } \\
\text { tiles }\end{array}$ & $\begin{array}{c}\text { Lowest } \\
\text { indica- } \\
\text { tors }\end{array}$ & $\begin{array}{c}\text { Highest } \\
\text { indica- } \\
\text { tors }\end{array}$ & \\
\hline \multicolumn{14}{|l|}{ Chernozem } \\
\hline podzolized & \multirow{4}{*}{ protein } & 11,0 & 10,0 & 12,4 & 7,6 & 19,2 & 221 & 13,7 & 12,8 & 14,3 & 10,0 & 18,5 & 12 \\
\hline typical & & 11,3 & 10,2 & 12,7 & 7,7 & 18,7 & 474 & 13,4 & 11,4 & 14,1 & 9,6 & 17,5 & 40 \\
\hline ordinary & & 11,9 & 10,0 & 12,8 & 7,6 & 17,2 & 113 & 13,7 & 11,5 & 14,6 & 9,4 & 16,1 & 18 \\
\hline southern & & 12,6 & 10,7 & 14,0 & 8,0 & 17,1 & 114 & 14,2 & 12,8 & 15,9 & 8,1 & 18,7 & 56 \\
\hline podzolized & \multirow{4}{*}{ gluten } & 23,0 & 19,8 & 26,7 & 13,6 & 33,4 & 104 & 29,0 & 22,0 & 30,0 & 20,4 & 33,1 & 9 \\
\hline typical & & 26,2 & 22,5 & 30,0 & 13,5 & 39,9 & 358 & 30,0 & 29,6 & 35,7 & 20,0 & 36,8 & 14 \\
\hline ordinary & & 28,1 & 24,4 & 32,3 & 15,1 & 38,2 & 102 & 30,6 & 25,0 & 34,60 & 18,3 & 38,5 & 50 \\
\hline southern & & 28,0 & 24,2 & 30,3 & 13,9 & 37,4 & 116 & 32,6 & 26,0 & 36,6 & 19,6 & 39,7 & 19 \\
\hline podzolized & \multirow{4}{*}{$\begin{array}{c}\text { Vitreous } \\
\text { ness }\end{array}$} & 61,0 & 52,4 & 89,0 & 40,0 & 96,0 & 62 & 62 & 55,5 & 69,0 & 41,0 & 93,0 & 9 \\
\hline typical & & 68,0 & 52,0 & 81,0 & 40,0 & 98,0 & 232 & 80 & 69,0 & 86,0 & 48,0 & 98,0 & 22 \\
\hline ordinary & & 75,0 & 60,0 & 88,5 & 40,0 & 97,0 & 89 & 93 & 87,0 & 97,0 & 47,0 & 98,0 & 11 \\
\hline southern & & 79,0 & 62,2 & 87,5 & 42,2 & 98,0 & 97 & 91 & 82,3 & 93,2 & 60,6 & 99,0 & 11 \\
\hline
\end{tabular}




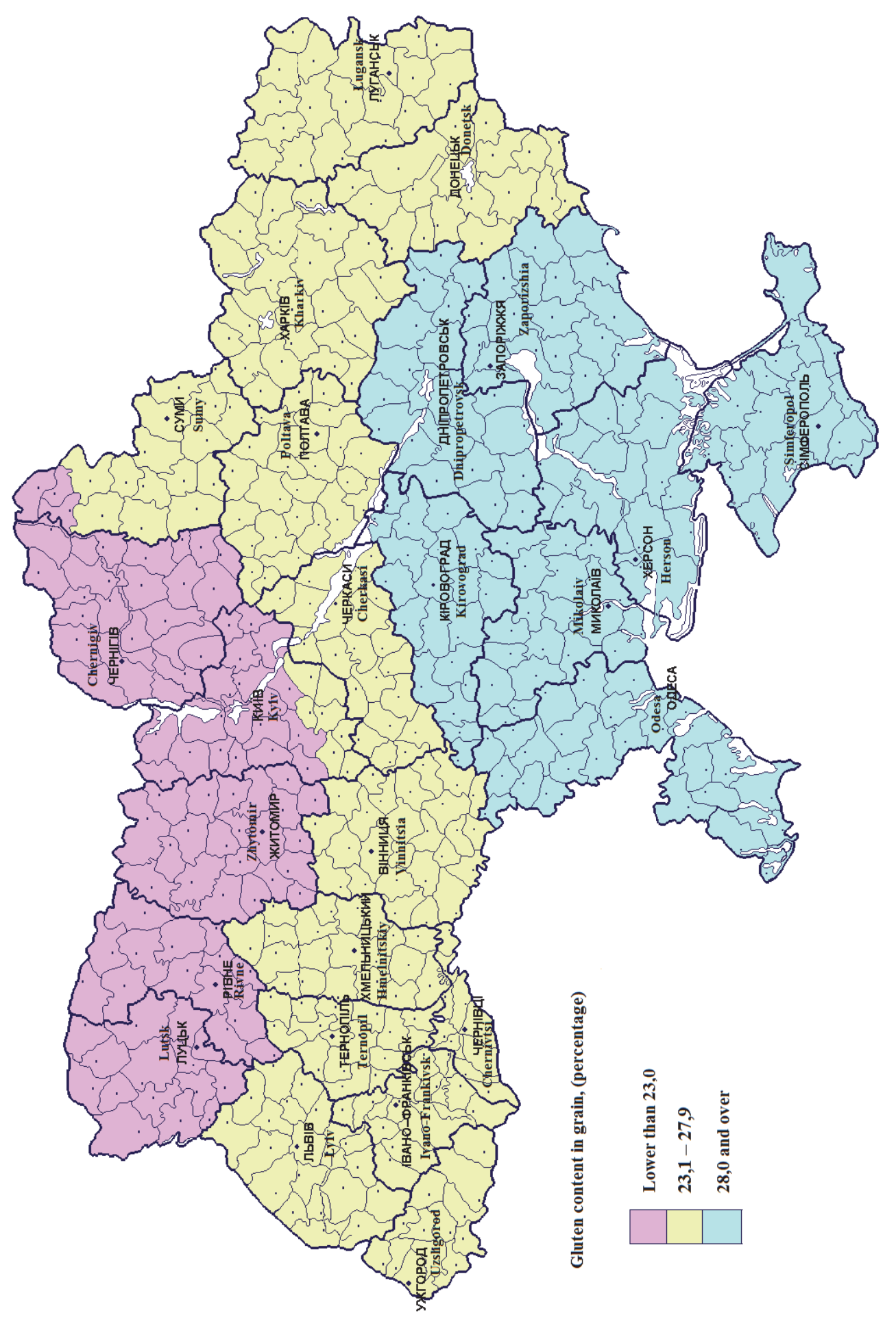

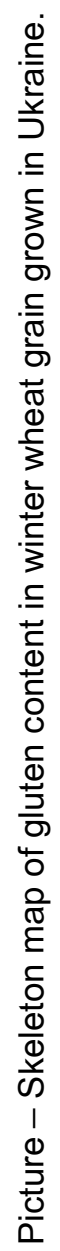


Normative indicators of gluten content in winter wheat grains also increase from $23.0 \%$ on chernozems podzolized to $28.1 \%$ on chernozems southern. The content of gluten in grains is significantly affected by the weather conditions of the steppe zone. The addition of mineral fertilizers also increases the content of gluten from $29.0 \%$ in chernozem podzolized to $32.6 \%$ - in chernozem southern.

The vitreousness content in wheat grain varies by type of black earth is $61-79 \%$. The extraction of mineral fertilizers increases the vitreousness in the forest-steppe to $62 \%$ on podzolized chernozem and up to $80 \%$ on typical chernozem; on soils of the Steppe - up to $91-93 \%$.

The spatial pattern of gluten content in winter wheat grains on the territory of Ukraine is established (figure). Low content of gluten in winter wheat grains grown in the Polissya zone (up to 23\%), the average (23.1 - 27.9\%) - forest-steppe, high ( $28 \%$ and more) - in the steppe zone (see picture).

\section{Conclusions}

In the conditions of the forest-steppe on the main types of chernozem, the normative indicators of the content of protein in winter wheat are: on podzolized chernozem - $11,0 \%$, of chernozem typical - 11,3, in conditions of the steppe on chernozem ordinary - 11,9, chernozem southern - 12,6; The content of gluten is $23.0 \%, 26.2 ; 28.1$ and $28.0 \%$, vitreousness - 61\%; $68 ; 75$ and $79 \%$. The introduction of mineral fertilizers increases the quality of winter wheat grains grown on chernozem of the forest-steppe and the steppe zones.

\section{Bibliography}

1. Lisovyi M.V. Influence of soil fertility on quality of winter wheat grain grown on not sod-podzolic soils of Polissya / M.V. Lisovyi, A.V. Komarista // Visn. of Agrar. Science - 2015 - № 11. - P. 10 - 12.

2. Boyko G.I. Features of crop formation and quality of winter wheat grain in connection with the type of soil and fertilizers in the southern part of Polessie / G.I. Boyko//Agrochemistry. - 1976. - №5. - P. 72 - 77.

3. Directory of normative indicators of quality of agricultural crops in different types of soil and climatic zones of Ukraine (Reference and normative information); ed. SA Balyuk, M.V. Lisovyi - Kh., 2016. - 45p.

4. Polupan M.I. Classification of soils of Ukraine / M.I. Polupan, V.B. Solovey, V.A. Velychko - K .: Agrar. Science, 2005. - P. 192 - 211.

5. Grain quality of winter wheat in the northern steppe / I.I. Hasanova, O.O. Pedash, E.L. Konopleva et al. // Bull. Inst. field Households in the steppe zone. - Dnepropetrovsk: New Idea, 2013. - No. 5. - p. 51-57.

6. Scientific basis of fertilization of winter wheat according to soil and vegetation diagnostics / M.M. Miroshnichenko, O.V. Dotsenko, E.V. Panasenko and others. - Kh.: FOP Fedorko M.U., 2013. - 32 p.

7. Vasilenko M.G. Effect of fertilizers on yield and quality of wheat / M.G. Vasilenko, G.I. Derik, M.P. Didkovsky // Chemistry. Agronomy. Service: All-Ukrainian edition on modern agrotechnologies. - 2011. - No. 11. - P. 24 - 29.

8. Atramentova L.A. Statistical Methods in Biology: A Textbook for Students at Higher Educational Institutions / L.A. Atramentova, O.M. Utevskaya - Gorlovka, 2008. - 248p.

9. Kobzar A.I. Applied Mathematical Statistics: for Engineers and Researchers / A.I. Kobzar - M: Phyzmathlit, $2006-816 p$.

10. Hlisnikovsky L. Effect of Mineral and Organic Fertilizers on Yield and Technological Parameters of Winter Wheat (Triticum aestivum L.) on Illimerized Luvisol / L. Hlisnikovsky, E. Kunzova / Polish Journal of Agronomy. 2014 - \# 17. - P. 18 - 24. 